\title{
Antibiogram of mastitis pathogens in the milk of crossbred cows in Namakkal district, Tamil Nadu
}

\author{
M. Jeykumar ${ }^{1}$, G. Vinodkumar ${ }^{2}$, Bimal P. Bashir ${ }^{3}$ and Sudhakar Krovvidi ${ }^{4}$ \\ 1. Veterinary Dispensary,Thayamangalam, Dist \& Tq - Shivangangaya, Tamil Nadu, India; 2. Department of Livestock \\ Production and Management, Veterinary College and Research Institute, Namakkal - 637002, Tamil Nadu, India; \\ 3. Department of Animal Husbundary Extension, Veterinary College and Research Institute, Namakkal - 637002, \\ Tamil Nadu, India; 4. Department of Animal Genetics and Breeding, Veterinary College and Research Institute, \\ Namakkal - 637002, Tamil Nadu, India
}

Corresponding author: G. Vinodkumar, email:drvinodlpm@gmail.com

Received: 20-09-2012, Accepted: 26-10-2012, Published online: 25-03-2013

\section{How to cite this article:}

J eykumar M, Vinodkumar G, Bashir BP and Krovvidi S (2013) Antibiogram of mastitis pathogens in the milk of crossbred cows in Namakkal district, Tamil Nadu, Vet. World 6(6):354-356, doi: 10.5455/vetworld.2013.354-356

\begin{abstract}
Aim: The present study was undertaken to ascertain the prevalence and drug sensitivity pattern of causative agents of mastitis in and around Namakkal, Tamilnadu, India.

Materials and Methods: A total of 74 milk samples were collected and bacterial isolates from 72 samples were obtained and subjected to in-vitro chemotherapeutic sensitivity test.

Results: Out of 72 samples, 32 (44.44\%) were found positive for Staphylococci species, 4 (5.5\%) for Streptococci species, 30 $(41.66 \%)$ for E.coli and $6(8.33 \%)$ for Klebsiella species. The drug sensitivity test performed irrespective of isolates, revealed sensitivity of organisms to various antibiotics and none of the isolates were found to be sensitive to penicillin $\mathrm{G}$.
\end{abstract}

Conclusion: Enrofloxacin was found to be more effective antibiotic among all the tested antibiotics.

Key words: antibiogram, bacterial isolates, mastitic milk.

\section{Introduction}

Mastitis is the inflammation of udder tissue causing pathological changes in udder parenchyma and characterized by physical, chemical and microbiological changes in milk [1]. It is one of the economically important diseases of dairy animals affecting quality and quantity of milk. Mastitis in dairy animals leads to economic losses in different forms viz. reduction in milk production $(70 \%)$, premature culling $(14 \%)$, veterinary expenses $(9 \%)$ and milk discarded or low graded (7\%) [2]. The global estimated economic loss per year due to mastitis amounts to USD 35 billion [3]. Whereas Indian Dairy Industry suffers a total monetary loss of over Rs.6000 crore per year [4]. Further mastitis has public health importance as it is one of the sources for communicable diseases such as tuberculosis, brucellosis, staphylococcal toxemia, septic sore throat, gastroenteritis etc. [5].

Mastitis is produced by interplay of the variety of pathogenic agents' viz. bacteria or fungus and management practices stressing the defense of udder. Over 135 microorganisms have been isolated from bovine inflammatory infections and bacteria are one of the major etiological agents of mastitis [6]. Mastitis is considered to be the most common cause of indiscriminate antibiotic use in dairy animals which leads to treatment failure, escalated treatment costs and

This article is an open access article licensed under the terms of the Creative Commons Attribution License (http://creativecommons. org/licenses/by/2.0) which permits unrestricted use, distribution and reproduction in any medium, provided the work is properly cited. development of resistance to antimicrobials. The multiplicity of the cause and emergence of resistance due to indiscriminate and prolonged use of antibiotics in absence of antibiogram is a major hurdle in the control of mastitis.

To overcome this problem and with due consideration to the economic losses, the present study was undertaken to ascertain current drug sensitivity pattern of causative agents of mastitis.

\section{Materials and Methods}

A total of 74 milk samples were aseptically collected from cows suffering from clinical mastitis from various places of Namakkal district of Tamil Nadu. The udder of each cow was thoroughly washed initially with potassium permanganate solution (1:1000) and wiped with clean cloth to allow drying. The mid stream milk was sampled using sterile swab aseptically and transported to the laboratory in ice pack for in-vitro chemotherapeutic sensitivity test.

The milk samples were cultured in Nutrient agar, Mac Conkey agar, EMB agar, Sabourads dextrose agar and nutrient broth (Himedia) and incubated at $37^{\circ} \mathrm{C}$ for 36 hours. The typical colonies were sub-cultured in a selective broth and subjected to battery of tests viz., Gram reaction, oxidase, catalase, IMViC, motility and growth on TSI slant for biochemical identification. Then, the colonies were transferred to Muller Hinton agar plates and streaked.

Drug sensitivity test was done by using Kirby Bauer discs. The antibiotic discs (Himedia) viz., 
Table-1. Kirby-Bauer disc sensitivity test

\begin{tabular}{lcc}
\hline Antibiotic & Zone of inhibition $(\mathbf{m m})$ & Total No. of sensitive samples \\
\hline Enrofloxacin & 24 & $34(94.44 \%)$ \\
Ciprofloxacin & 23 & $33(91.66 \%)$ \\
Oxytetracycline & 13 & $32(88.55 \%)$ \\
Amoxicillin & 12 & $29(80.55 \%)$ \\
Gentamicin & 10 & $29(80.55 \%)$ \\
Streptomycin & 10 & $20(55.5 \%)$ \\
Penicillin - G & 6 & $0(0 \%)$ \\
\hline
\end{tabular}

Table-2. Biochemical tests.

\begin{tabular}{lccccc}
\hline Bacterial isolates & Oxidase test & Catalase test & IMViC test & Motility test & Acid production on TSI slants \\
\hline Staphylococci spp. & - & + & --- & - & - \\
Streptococci spp. & - & - & --- & $\mathrm{Nil}$ \\
E.coli & - & + & ++- & + & $\mathrm{Nil}$ \\
Klebsiella spp. & - & + & -+++ & $\mathrm{Y} / \mathrm{H}_{2} \mathrm{~S}(-)$ & $\mathrm{Y} / \mathrm{Y} / \mathrm{H} \mathrm{S}(-)$ \\
\hline
\end{tabular}

$(-)$ = Negative, $(+)$ = Positive, $\mathrm{Y}$ - yellow (acid), $\mathrm{H}_{2} \mathrm{~S}(+)$ Positive, $\mathrm{H}_{2} \mathrm{~S}(-)$ Negative.

amoxicillin $(30 \mu \mathrm{g})$, ciprofloxacin $(5 \mu \mathrm{g})$, enrofloxacin $(10 \mu \mathrm{g})$, gentamicin $(10 \mu \mathrm{g})$, oxytetracycline $(30 \mu \mathrm{g})$, penicillin - G (10 units), and streptomycin $(10 \mu \mathrm{g})$ were placed on the surface of charged agar plates aseptically at equidistant from each other. The plates were incubated at $37^{\circ} \mathrm{C}$ for 36 hours. The susceptibility of organisms to different drugs was observed by measuring zone of inhibition [7].

\section{Resutls and Discussion}

Out of 74 samples of mastitic milk, 72 samples showed bacterial growth and two samples showed for yeast (Candida species) growth. Growth of yeast was confirmed by inoculating the milk sample in Sabourads-dextrose agar. Out of 72 samples, 32 $(44.44 \%)$ were found positive for Staphylococci species, $4(5.5 \%)$ for Streptococci species, $30(41.66 \%)$ for E.coli and $6(8.33 \%)$ for Klebsiella species. The drug sensitivity test performed irrespective of isolates, revealed sensitivity of organisms to various antibiotics and none of the isolates were found to be sensitive to penicillin G (Table-1). The result of biochemical tests are given in Table-2.

The present study revealed that Staphylococci $s p$. was the major pathogen causing mastitis with high prevalence followed by E. coli which is in accordance with other reports [8-13]. The reports from other parts of the country [14-16] also indicate the highest prevalence of Staphylococci followed by other mastitogenic bacteria. The higher incidence of Staphylococci indicates unhygienic milking practices as this pathogen is mainly spread during milking via milkers' hands [17]. This also might be due to harbouring of the organism in the skin, udder and milk of the infected gland which acts as reservoir $[18,19]$. Whereas prevalence of E.coli is an indication of poor hygienic practices in dairy environment, as these organisms originate from the cow's environment and infect the udder through the teat canal. Contamination of end of the teat is a major predisposing factor in the development of environmental mastitis [17].

Table-1 indicates the zone of inhibition and antibiotic sensitivity of the isolates. The antibiotic susceptibility test of bacterial isolates revealed the sensitivity in the descending order of Enrofloxacin (94.44\%), Ciprofloxacin (91.66\%), Oxytetracycline (88.55\%), Amoxicillin (80.55\%), Gentamicin (80.55\%), and Streptomycin (55.5\%). Enrofloxacin has been found to be the most sensitive (94.44\%) among the battery of antibiotics used in the invitro study which was in accordance to some of the reports $[16,20-23]$. Few reported [8,11,13,14,24] antibiotics other than enroflooxacin as most effective drug from the studies done in various parts of country contrary to the present findings. The studies [25-28] from different parts of Tamil Nadu reported the sensitivity of mastitis causative organisms to other antibiotics. Isolates in the present study showed moderate sensitivity or resistance to Gentamicin, Streptomycin and Penicillin - G. Indiscriminate and frequent use of these antibiotics in animals could be the reason for their ineffectiveness against bacterial isolates. A similar observation of resistance to Penicillin was also observed [10,11,23,25,28,29].

The alarming level of less susceptibility or more resistance of organisms to a particular drug might be due to the prolonged exposure to the same drug. Considering the varied spectrum of pathogens resulting in mastitis in different geographical areas its control needs the selection of suitable antimicrobial by establishing an antibiogram. Hence, the control of mastitis should be by a definite regime of administration of antibiotics and holistic approach to the disease management.

\section{Authors' contribution}

$\mathrm{MJ}$ and SK conceived the idea and were involved in lab analysis along with GV. MJ and BPB collected samples from the field. GV and SK drafted and revised the manuscript. All authors read and approved the final manuscript.

\section{Acknowledgements}

The authors are thankful to the Dean, Veterinary College and Research Institute, Namakkal, Tamil $\mathrm{Nadu}$, India for providing the necessary facilities to 
carry out the work.

\section{Competing interests}

Authors declare that they have no competing interest.

\section{References}

1. Radostitis, O.M., Gay, C.C., Blood, D.C. and Funchcliff, K. W. (2000) Veterinary medicine: A text book of the disease of cattle, sheep, goat, horse and pigs. $9^{\text {th }}$ Edition W.B.Saunders, London.

2. National Mastitis Council. (1996) Current concepts in bovine mastitis.www. cow-mastitis. com. Retrieved on 1609-2012.

3. Sharma, N., Maiti, S. K. and Sharma K. K. (2007) Prevalence, etiology and antibiogram of microorganisms associated with subclinical mastitis in Durg, Chattisgarh State (India). Int. J. Dairy Sci., 2: 145-151.

4. Ranjan, R., Gupta, M. K., Singh, K.K. and Jha, D. K. (2008) Comparative efficacy of Papanicolaou stain and Leishman stain in the cytological study of bovine mastitis. Indian J. Vet. Pathol., 32: 277-279.

5. Kalorey, D.R. (2001) Future prospects for mastitis control. In: Proceedings of VIII Annual Conference of Indian Association for the advancement of Veterinary Research held at Ludhiana, 81-85.

6. Hawari, A. D. and Fawzi, A. (2008) Prevalence and distribution of mastitis pathogens and their resistance against antimicrobial agents in dairy cows in Jordan. Am. J. Anim. Vet. Sci., 3: 36-39.

7. Bauer, A.W., Kirby, W.M., Sherries, J.C. and Turk M. (1966) Antibiotic susceptibility testing by a standardized single disc method. American Journal of Clinical Pathology. 45: 493496.

8. Sumathi B. R., Veeregowda, B. M. and Gomes, A.R.. (2008) Prevalence and antibiogram profile of bacterial Isolates from clinical bovine mastitis. Vet. World, 1(8): 237-238.

9. Amith Kumar, Dwivedi, S. K. and Gupta M. K. (2010) Bacterial prevalence and antibiotic resistance profile from bovine mastitis in Mathura, India. Egyptian Journal of Dairy Science.38(1):31-34.

10. Harini H. and Sumathi, B.R. (2011) Screening of bovine milk samples for sub-clinical mastitis and antibiogram of bacterial isolates. Vet. World, 4(8):358-359.

11. Mahantesh. M. K and Basappa. B. K. (2011) Prevalence And Antimicrobial Susceptibility Of Bacteria Isolated From Bovine Mastitis. Advances in Applied Science Research, 2 (6):229-235.

12. Ranjan R, Gupta, M. K. and Singh K. K. (2011) Study of bovine mastitis in different climatic conditions in Jharkhand, India. Vet World, 4(5): 205-208.

13. Tufani N.A., Makhdoomi, D.M. and Hafiz, A. (2012) Epidemiology and therapeutic management of bovine masititis. Indian J. Anim. Res., 46(2): 148-151.

14. Das P. K. and Joseph E. (2005) Identification And Antibigram Of Microbes Associated With Buffalo Mastitis
In Jabalpur, Madhya Pradesh, India. Buffalo Bulletin, 24 (1): 3-9.

15. Sharma, A. and Sindhu N. (2007) Occurrence of clinical and subclinical mastitis in buffaloes in the State of Haryana (India). Ital.J.Anim.Sci., 6, (2): 965-967.

16. Bhanot, V., Chaudhri, S.S., Bisla, R.S. and Singh H. (2012) Retrospective Study On Prevalence And Antibiogram Of Mastitis In Cows And Buffaloes Of Eastern Haryana. Indian J. Anim. Res., 46 (2): 160- 163.

17. Bradley, A. J. (2002) Bovine mastitis an evolving disease, The Vet. J., 164: 116-128.

18. Spencer, G.R. and Lasmanis J. (1952) Reservoirs of infection of Micrococcus pyogenes in bovine mastitis. Am.J. Vet. Res., 13: 500.

19. Davidson, I. (1961) Observation on pathogenic Staphylococci in dairy herd during a period of six years. Res. Vet. Sci. 2:22

20. Kumar, R. and Sharma A. (2002) Prevalence, etiology and antibiograms of mastitis in cows and buffaloes in Hisar, Haryana. Indian J. Ani. Sci., 72: 361-363.

21. Sahoo, S. S., Sahoo, N. and Parida G. S. (2009) Antibiogram of bacterial isolates from bovine subclinical mastitis. Indian Vet. J., 86(12):1298-1299.

22. Joshi, S., S. Gokhale (2006).Status of Mastitis as an Emerging Disease in Improved and Periurban Dairy Farms in India. Ann. New York Acad. Sci., 1081: 74-83.

23. Ranjan, R., Gupta, M. K., Singh, S. and Kumar S. (2010) Current trend of drug sensitivity in bovine mastitis. Vet. World, 3(1):17-20.

24. Sudhakar, P. A., Narendra, V.K., Vikas, M.S. and Mangesh S.M. (2009) Prevalence and current antibiogram trend of mastatic agents in Udgir and its vicinity, Maharashtra state, India. Int. J. Dairy Sci., 4(3):117-122.

25. Paul, W. M., Parthiban, M., Menaka, R. and Nainar A. M. (2000) The occurrence and antibiogram of bacterial isolates from milk samples of bovine subclinical mastitis. Indian Journal of Animal Health, 39(2):79-81.

26. Elango, A., Doraisamy K.A., Rajarajan G. and Kumaresan G. (2010) Bacteriology of sub clinical mastitis and antibiogram of isolates recovered from cross bred cows. Indian J. Anim. Res., 44 (4): 280 - 284.

27. Krithiga, N., Antony, P. X., Mukhopadhyay, H. K., Pillai, R. M., Vijayalakshmi, P., Thanislass, J. and Subbareddy K. V. (2011) Species Characterization And Antibiogram Profile Of Staphylococci Isolates In Clinical Bovine Mastitis. Animal Science Reporter, 5 (1): 3-8.

28. Mubarack H M., Doss, A., Vijayasanthi, M. and Venkataswamy R. (2012) Antimicrobial drug susceptibility of Staphylococcus aureus from subclinical bovine mastitis in Coimbatore, Tamilnadu, South India. Vet. World, 5(6): 352355 .

29. Eswaran, M. A., Sukumar, K. E. K., Malmarugan, S., Manikandan, A. and Geethanjali S. (2011) Detection of virulent gene for nuclease (nuc) in Staphylococcus aureus isolated from subclinical mastitis. Indian Journal of Field Veterinarians, 7(1):17-20. 